\title{
Crisis of values as a result of the breakdown of pre-modern society: On the example of the romantic love convention
}

\author{
Jarosław Barański \\ https://orcid.org/0000-0001-5670-9391 \\ Dominik Stosik \\ https://orcid.org/0000-0003-1764-9212
}

The crisis of values is considered in this paper as a consequence of pre-modern society's disintegration. It is also attributed to the fact that modern times are not conducive to consolidating value systems due to ongoing dynamic cultural transformations. Such conclusions are drawn by taking up the case of romantic love convention, its disintegration and atrophy in premodern society. Shown against this background is an entirely different present-day situation of individuals as subjects in control of their emotions, abilities as well competences and ultimately their own life choices.

Keywords: romanticism, modernity, axiology, philosophy of culture

JAROSŁAW BARAŃSKI, PhD, head of Department of Humanistic Sciences in Medicine, Wroclaw Medical University; address for correspondence: ul. Mikulicza-Radeckiego 7, 50-368 Wrocław; e-mail: jaroslaw.baranski@umed.wroc.pl

DOMINIK STOSIK, graduate of the Westfälische Wilhelms-Universität Münster, Christians-Albrecht-Universität zu Kiel, student $5^{\text {th }}$ year student at Wroclaw Medical University; address for correspondence: ul. Mikulicza-Radeckiego 7, PL 50-368 Wrocław; e-mail: dominik.stosik@student.umed.wroc.pl 


\section{Romantic triad in the convention of love}

Separation and disconnection, one of the key elements of romantic lyricism, are always present when we describe the most intense affect - love. Separation affects those who are not and never will be one, either as lovers or spouses. It has its real dimensions in space and time, is of material and spiritual character, and can even reach eternity: "In heaven even the soul does not connect with the soul"1 ("Sonnets, I"), wrote Juliusz Słowacki, one of the greatest romantic Polish poets. Love supports and emotionally fixates the farewell gesture and opens up all possibilities of non-fulfillment. It is parting that awakens love, not getting closer to each other. The evoked memory of parting functions as the basis of the affect: "Separated - but one remembers the other." (Separation). Romantic love exists only due to separation:

"But though never, nowhere we shall connect,

Let us be silent for a while and then call each other again,

Like two sad nightingales, attracting each other with cry."

Such love is accompanied by many complex feelings and states: suffering, despair, sorrow, longing, hatred, anger, humiliation, and the sense of injustice. These deep feelings indicate a loss that merits compensation which, in Romanticism, was in the form of lyrical reward represented by exaltation. Such reward helped people love despite separation, anger, the feeling of harm and humiliation, and moreover, along with these feelings. The greatest philosopher among Polish Romantic poets, Zygmunt Krasiński, confirmed that in letters to his beloved Delfina Potocka:

"And for me separation is the emblem of love,

For how many times I would have had hated in life,

By reconnection fate would scoff at me."4

\footnotetext{
${ }^{1}$ Juliusz Słowacki, Poetry[Poezje] (Kraków: Zielona Sowa, 2003), 7.

${ }^{2}$ Ibid., 34.

${ }^{3}$ Ibid.

${ }^{4}$ Zygmunt Krasiński, Selected Letters, a letter to Delfina Potocka as of 14.09.1843 [Listy wybrane, List do Delfiny Potockiej z 14.09.1843], ed. Tadeusz Pini (Warszawa: Parnas Polski, 1937), 268.
} 
The strength and durability of love was ensured not so much by the presence of affection, but how it was controlled by people's memory and imagination evoking complex emotional states. In exalted love, one establishes a permanent connection with the content of own mental states and love becomes a game of, often contradictory, emotions. By compensating this separation and disconnection with exaltation, the lyrical I falls for the romantic convention of love. By saying nothing about sensuality, body or sexuality, romantic lyric poetry seems to be "disembodied". This is due to the fact that class relations govern the body, and sexuality is reduced only to maintaining its reproductive aspect.

The convention of romantic love is created by a triad of affect, marriage, and sexuality. It contains social and economic rules with three separate forms of social behavior: love excludes marriage, marriage excludes sexuality (apart from procreation), and sexuality excludes love. What conventionalizes these behaviors and their mutual separation is an economic contract that precedes marriage. By functioning in strong family and class relationships of pre-modern society, such contract determined the existence of the relationship (le dispositif d'alliance ${ }^{5}$ ), created conditions for its social reproduction, defined the panoply of spouses' biographical scenarios, and imposed frameworks of emotional and sexual expression.

In a marriage like that, love, which manifested itself as affectation, desire, and infatuation, was redundant, accidental, and from the perspective of its social function, insignificant and non-defining. This randomness of love is not at all negative. Basically, romantic love was free from the matrimony, which, irrespective of the economic contract, institutionalized the spouses' procreative behavior. Moreover, love was free from sexuality because this kind of emotional exaltation could not be materialized as a sexual act that banishes exaltation.

\section{Disintegration of the emotional convention - symptoms of the crisis of values}

In the first chapter of Hermann Broch's novel Die Schlafwandler (19281932), entitled 1888 Pasenow oder die Romantik, the author presents protagonists

\footnotetext{
${ }^{5}$ Michel Foucault, La volonté de savoir (Paris: Éditions Gallimard, 1976), 140.
} 
entangled in the Romantic emotional convention and whose emotional situation may be defined as "helpless", since the romantic convention is their only support and a way to escape tiredness and "vegetative indifference". Moreover, it is a refusal to accept possible offers of culture, even when protagonists notice the first signs of the convention breakdown. Protagonists are "helpless" because their abandonment of Romanticism is not supported by any other emotional convention and the fear of unknown is so great that not only Joachim, who represents pre-modern social order, but also Bertrand, who represents modernity, quickly adhere to the Romantic convention and, by being emotionally engaged, try to avoid indifference and emptiness. However, they both do it fearfully: "surviving forms are always full of inertia and it needs great weariness to devote to a dead and romantic emotional convention. It comes with a large dose of desperate immobility."

Joachim and Bertrand, as well as Elisabeth, who is an object of their affection, feel suffocated by Romanticism as pre-modernity dies with its own conventions and unmasks itself in boredom, hypocrisy and confusion. The only salvation for protagonists is to, against all odds, adhere to an already exhausted convention. It is a declaration of belonging to a decadent world that can reveal and foreshadow nothing but axiological decomposition.

Joachim perceives Elisabeth as an impeccable, angelic and, at the same time, asexual being, because any thought of having a sexual desire for her, any idea of her sensual corporeality would mean desecration, a disgrace of her innocence and purity. Joachim is incapable of love as a husband, because he seeks a romantic feeling. Since "with romanticism you cannot take care of anyone", he recognizes his own inability to be a husband.?

Bernard, on the other hand, follows the Romantic convention and confesses his absolute love for Elisabeth, love which is a mystery impossible to establish neither by mutual familiarity nor by being together out of habit. "There is only one true pathos by the name of eternity, it must acquire a negative character and change its name to: nevermore-shall-we-meet. If I leave now, eternity will

${ }^{6}$ Hermann Broch, Die Schlafwandler. Eine Romantrilogie (Bonn: Suhrkamp, VG Bild-Kunst, 2005), 60-61.

${ }^{7}$ Ibid., 88 . 
take place, you will become eternally distant and I will have the right to say that I love you."

Paradoxically, the fulfillment of romantic love lies in its non-fulfillment, simply - in parting. Bernard proves it by saying:

"- Unspeakably, I long for you«.

Then she smiled: - »Are you leaving?»

$-»$ Yes«.

She glanced up doubtfully and in disbelief; he repeated, »No, we will not see each other again «"”

\section{From pre-modernity to modernity}

The breakdown of emotional conventions indicates not only the breakdown of pre-modern societies but also, since social rules and axiological conventions are disintegrated, the crisis of values. Modernity has shattered class-family dependencies and generational ties in the process of individualization which, due to high standards of living and social security, was unprecedentedly far reaching and dynamic. According to Ulrich Beck, "due to the breakdown of historical continuum, people have freed themselves from traditional class circumstances or family ties and, at the same time, they have become stronger and capable of accepting their own fate on the labor market with all its risks, opportunities and contradictions" ${ }^{10}$. Therefore, in modernity class-family relationships no longer determine available life scenarios which can guarantee the source of income which means that everyone can choose their own paths by controlling skills and competences on the labor market and not by controlling emotions (like in Romanticism).

Due to the process of individualization, people are losing their axiological "garment" that located them socially and gave them certain social significance. Moreover, this "garment", due to all exiting conventions, allowed taking or evading actions, and most importantly, experience the world as something familiar,

\footnotetext{
${ }^{8}$ Ibid., 109.

${ }^{9}$ Ibid., 154.

${ }^{10}$ Ulrich Beck, Risikogesellschaft. Auf dem Weg in eine andere Moderne (Frankfurt am Main: Suhrkamp, 1986), 116.
} 
clear and predictable. In the process of transition from pre-modernity to modernity, people have lost their social, symbolic requisites or, more accurately, by referring to Pierre Bourdieu ${ }^{11}$, they have lost their symbolic capital that included cognitive abilities helping them build social identity. The world has become unfamiliar to an individual and an individual feels unfamiliar in this world.

From the perspective of possible social investment, it is everything and nothing, only an abstract carrier of consumption possibilities. Socially naked individuals have no class emblems, which evidences their uprooting from social and cultural traditions. The body is the only thing that remains and is at disposal. Therefore, transition to the modern world is responsible for the crisis of identity.

Modern people are naked and cannot cover themselves with traditions of dependencies, relationships and axiological conventions and this nakedness requires some kind of compensation, i.e., creating one's own identity. Since people cannot rely on anything outside, they rely on themselves. According to Anthony Giddens, this compensation manifests itself in reflexive planning of one's own life, when rational taking care of the body becomes an existential project that develops person's identity, with such regulated control being essential in maintaining own biographical continuity and identity ${ }^{12}$. Therefore, our identity is focused on the body which, with its own physiological states and appearances, is what we choose among all available life scenarios. ${ }^{13}$ The body is covered with symbolic capital we accumulate in the course of life. ${ }^{14}$

Moreover, any relationship, including marriage, belongs to this embodied life scenario. The emotional convention of romantic love has faded or disappeared due to three reasons. Firstly, due to the lack of economic contract prior to marriage. Secondly, and as a consequence, people have freed themselves from strong class and family pressure (oppression). Thirdly, participation on the labor market allowed them building their own biographies and identities. People have been culturally equipped with the possibility of acquiring skills to manage one's own life.

\footnotetext{
${ }^{11}$ Pierre Bourdieu, "The forms of capital," in Handbook of Theory and Research for the Sociology of Education, Westport, ed. John Richardson (Westport, CT: Greenwood, 1986), 241-258.

${ }^{12}$ Anthony Giddens, Modernity and Self-Identity. Self and Society in the Late Modern Age (Cambridge, Oxford: Blackwell Publishers, 1991), 57.

${ }^{13}$ Chris Shilling, The Body and Social Theory (London: SAGE Publications, 2005), 3.

${ }^{14}$ Mike Featherstone, "Post-bodies, Aging and virtual reality," in Images of aging. Cultural Representations of Later Life, eds. Mike Featherstone, Andrew Wernick (London: Routledge, 1995), 231248.
} 
In modernity love is still a choice, but based on a completely different convention, in which separate elements of the romantic triad, i.e., affect, sexuality and marriage, have been fused together and are now represented by sexual attraction. Therefore, love has become a part of our biography and is only an expression of embodied subjectivity. However, to define marriage or any other relationship, sexual attraction seems necessary.

As one of the possible life choices rooted in corporality, love has become fragile and perishable, thereby triggering fear and existential anxiety. This is because another person, with his or her own existential project, has gained some control over our emotions, body and life. Due to this tension and conflict, modern convention of love is simply unstable, having no axiological support, demanding a constant search for stability and, at the same time, creating tools that help escape this stability, so that love would not jeopardize any potential life choices.

\section{Modern creation of subjectivity}

In the modern world, people have freed themselves from traditional ties and become bodies without previous symbolic requisites conveying their social meaning and defining their identity. This crisis has triggered new tools for building own identity based on skills and competences, which has made all life scenarios possible. As a result, "the more choice people have, the more varied life they can create for themselves." ${ }^{15}$ Thus, even if at the end of the pre-modernity people felt helpless, in modernity all variants of biographical life opened up allowing them construct different life scenarios.

Therefore, the model of life based on the continuous development of one's own competences, i.e., abilities and skills helping people manage their own lives according to their needs, expectations and desires, has become increasingly popular. As consumers, people keep up appearances of self-determination, and the only limitations seem to be associated with their subjectivity. A modern man gains confidence that the consumer's position depends on the competitiveness on the labor market, which is why, according to Bernd Stegemann: "In order

${ }^{15}$ Gerhard Schulze, Die Erlebnisgesellschaft. Kultursoziologie der Gegenwart (Frankfurt/New York: Campus Verlag, 2000), 76. 
to remain competitive, people need to create their biography as a history of educational success. Accordingly, the success of their existence is based on successful individualization." ${ }^{16}$ However, the more people surrender to this biographical convention, the more disappointed they are: "Individual freedom is accompanied by anxiety and indecisiveness because each choice is at the same time a waste of potentially available opportunities which makes people slaves to the randomness of opportunities [Maybe der Kontingenz]. The fact that people constantly miss infinite number of opportunities is their torment [....]. Everything slips out of their hands whenever they grasp it, because what they have chosen cannot be compared to the thousands of opportunities they have already rejected." ${ }^{\text {17 }}$

This model of life is based on the illusion that better education allows greater consumption and, consequently, provides happiness and a sense of "subjective uniqueness". Thus, each failure manifests itself as something irrational, as loss and harm, which defies algorithms of planning own biography. Then there is a sense of disappointment or disillusion, which forces an individual to compensate for this loss and harm by choosing another life scenario.

This game of expectations, disappointments, choices and failures only confirms the randomness of existence, which is suppressed by freedom of consumption and rationality of education. Any attempt to gain experience is immediately being tested by rules of social life which are rapidly changing due to technical and technological progress. The modern world is unstable, free from tradition, open to all possibilities - like a reservoir of values that cannot root anywhere.

Devaluation of experience, which is a permanent crisis of values

Our values are fixed in conventions of experiencing and understanding the world, in the required rules of behaviors and actions providing for the generational experience. If values are unstable and volatile, we are dealing with the axiological crisis. Today, this crisis might be compensated by new offers from the catalogue of values, but none of them can take the form of a convention. We lack time to establish these values in our own experience, because the experience itself is rapidly devaluating. Life turns into speed, as Paul Virilio put it: "To live, to be

\footnotetext{
${ }^{16}$ Bernd Stegemann, Lob des Realismus (Berlin: Theater der Zeit, 2015), 64.

${ }^{17}$ Ibid., 70.
} 
alive, means to be speed [...], my life, my biography is all speed." ${ }^{18}$ Hence, if we treat moral knowledge and cognitive abilities as a symbolic capital which, according to Pierre Bourdieu, is passed down from generation to generation, we can conclude that its lack comes from this biographical speed. Simply, there is not enough time to pass this capital to the next generations. What is more, this capital loses its value in the accelerated progress. If people are slow, they are more confused and alienated, have higher risk of losing their social positions and tools allowing them shape own biographies. We can no longer lag behind and rely on own life experience. We need to be impatient and in a rush, because, according to Odo Marquard: "If you want to achieve something new by changing and improving what already exists, you must do it quickly." 19

This rush responds to the pace of social changes and confirms the exhaustion of experience that is constantly outdated by social and technical progress. In Apologie des Zufälligen Odo Marquard wrote that faster changes indicate the accelerated aging of experience. ${ }^{20}$ People are detached from the world that is becoming increasingly unfamiliar and need to learn it all over again. Therefore, they need to educate themselves, acquire new competences and skills to control the alienation of everyday life. Education schemes, which are characterized by dynamic changes, seem to be their most important biographical choices.

This is one aspect of modernity that presents modernization as a galloping obsession of everyday life. Technological progress is unrelenting, mainly in relation to its own constructs. Its essence is to forget the previous level of development, thereby condemning the former message to silence. Patina covers the rejected products of technical culture and they lose their only sense of existence - utility. In the vicious circle of novelty, present becomes its own memory, or rather, an empty space after it.

When conventions disappear, all that remains is the mosaic of values, similar to Kaiser Panorama or Cabinets of Wonder. Modern people choose from this mosaic and achieve their own goals as effective as possible. Hence, the randomness

\footnotetext{
${ }^{18}$ Paul Virilio, "Fahrzeug," in Aisthesis. Wahrnehmung heute oder Perspektiven einer anderer Ästhetik, eds. Karlheinz Barck, Peter Gente, Heidi Paris, Stefan Richter (Leipzig: Reclam, 2002), 48.

${ }^{19}$ Odo Marquard, Skepsis und Zustimmung, Philosophische Studien (Stuttgart: Reclam, 1995), 48.

${ }^{20}$ Id., Apologie des Zufälligen. Philosophische Studien (Stuttgart: Reclam, 1987).
} 
of existence is associated with the axiological randomness, which gives rise to the crisis of values, because today our task is not to determine axiological signposts but to place them in our lives. A lack of conventions, which are a fixed repertoire of values we can refer to, evidences the loss of control over ourselves, over the others, and over the nearest world. This reinforces the sense of insecurity and increases anxiety about the future. Openness to the future means accepting everything that is unpredictable, undesirable, unwanted or even hostile and this perhaps constitutes the crisis of values.

\section{References}

Beck, Ulrich. Risikogesellschaft. Auf dem Weg in eine andere Moderne. Frankfurt am Main: Suhrkamp, 1986.

Bourdieu, Pierre. "The forms of capital." In Handbook of Theory and Research for the Sociology of Education. Edited by John Richardson, 241-258. Westport: Greenwood, 1986.

Broch, Hermann. Die Schlafwandler. Eine Romantrilogie. Bonn: Suhrkamp, VG Bild-Kunst, 2005.

Featherstone, Mike. "Post-bodies, Aging and virtual reality." In: Images of aging. Cultural Representations of Later Life. Edited by Mike Featherstone, Andrew Wernick, 231-248. London: Routledge, 1995.

Foucault, Michel. La volonté de savoir. Paris: Éditions Gallimard, 1976.

Giddens, Anthony. Modernity and Self-Identity. Self and Society in the Late Modern Age. Cambridge, Oxford: Blackwell Publishers, 1991.

Krasiński, Zygmunt. Listy wybrane, List do Delfiny Potockiej z 14.09.1843. Edited by Tadeusz Pini. Warszawa: Parnas Polski, 1937.

Marquard, Odo. Apologie des Zufälligen. Philosophische Studien. Stuttgart: Reclam, 1987.

Marquard, Odo. Skepsis und Zustimmung. Philosophische Studien. Stuttgart: Reclam, 1995.

Schulze, Gerhard. Die Erlebnisgesellschaft. Kultursoziologie der Gegenwart. Frankfurt/New York: Campus Verlag, 2000.

Shilling, Chris. The Body and Social Theory. London: SAGE Publications, 2005.

Słowacki, Juliusz. Poezje. Kraków: Zielona Sowa, 2003.

Stegemann, Bernd. Lob des Realismus. Berlin: Theater der Zeit, 2015.

Virilio, Paul. "Fahrzeug." In Aisthesis. Wahrnehmung heute oder Perspektiven einer anderer Ästhetik. Edited by Karlheinz Barck, Peter Gente, Heidi Paris, Stefan Richter, 47-70. Leipzig: Reclam, 2002. 


\section{Streszczenie}

\section{Kryzys wartości jako rezultat rozpadu przednowoczesnego społeczeństwa - na przykładzie konwencji miłości romantycznej}

Kryzys wartości jest określany w artykule jako efekt rozpadu społeczeństwa przednowoczesnego i jednocześnie jako rezultat niezdolności współczesności do utrwalenia systemów wartości ze względu na dynamicznie przebiegające zmiany kulturowe. Pretekstem do rozważań jest konwencja miłości romantycznej w społeczeństwie przednowoczesnym, jej rozpad i zanik, ukazując całkowicie odmienną współczesną pozycję jednostki jako podmiotu zarządzającego swoimi emocjami, zdolnościami kompetencjami i - ostatecznie - własnymi wyborami biograficznymi.

Słowa kluczowe: romantyzm, nowoczesność, aksjologia, filozofia kultury.

\section{Zusammenfassung}

Die Wertekrise als Ergebnis des Zerfalls der vormodernen Gesellschaft. Am Beispiel der Konvention der romantischen Liebe

Die Wertekrise wird im Artikel als Ergebnis des Zerfalls der vormodernen Gesellschaft bezeichnet, gleichzeitig auch als Ergebnis der Unfähigkeit der Gegenwart, die Wertesysteme aufgrund der sich dynamisch vollziehenden kulturellen Veränderungen zu festigen. Als Anlass zum Nachdenken gilt die Konvention der romantischen Liebe in der vormodernen Gesellschaft, ihr Zerfall und Verschwinden, was eine völlig andere gegenwärtige Stellung des Individuums als eines Subjekts aufzeigt, das über seine Gefühle, Fähigkeiten, Kompetenzen und letztendlich seine eigenen biografischen Entscheidungen verfügt.

Schlüsselworte: Romantik, Modernität, Axiologie, Kulturphilosophie

Informacje o Autorach:

JAROSŁAW BARAŃSKI, dr hab., kierownik Zakładu Humanistycznych Nauk Lekarskich, Uniwersytet Medyczny we Wrocławiu; adres do korespondencji: ul. Mikulicza-Radeckiego 7, 50-368 Wrocław; e-mail: jaroslaw.baranski@umed.wroc.pl 
DOMINIK STOSIK, absolwent Westfälische Wilhelms-Universität Münster, Christians-Albrecht-Universität zu Kiel, student V roku Uniwersytetu Medycznego we Wrocławiu; adres do korespondencji: ul. Mikulicza-Radeckiego 7, 50-368 Wrocław; e-mail: dominik.stosik@student.umed.wroc.pl 